\title{
THE CONNEXION BETWEEN ENGLISH AND NORMAN RITES.
}

THE Norman conquest influenced ecclesiastical affairs at least as strongly as the political condition of England. It is true that Norman influence was not unknown in the last days of the AngloSaxon monarchy, but with the advent of William it at once became paramount. Among the revolutions which it introduced was that by which the organization, that we now know as the Cathedral system, took possession of the mother churches of many English dioceses. It is well known that the organization which now holds the field alone in our Cathedrals was in preReformation days only one of two co-existing systems : for some Cathedral bodies were monastic, and only one half of the English Cathedrals at the time of the suppression of the greater monasteries were served by secular canons according to the plan which in a modified form still holds its place there. The Norman invasion was indeed not without its effect upon the great Benedictine Houses that served at Canterbury, Rochester and elsewhere as Cathedral bodies: and in the transformation by which the old Saxon Bishopstools were removed from small sites to more commanding centres, the monastic system became associated with the East Anglian bishopric at Norwich, while new monastic Cathedral Churches soon after came into existence, Benedictine at Ely and Augustinian at Carlisle. But it was in the other system-the system of secular canons-that the greatest effect was made: for a new model was introduced to supersede the old lax ways, which, in spite of the reforms of S. Dunstan and S. Ethelwold, the Saxon ecclesiastic still loved. The movement began with the foundation, within a few months of one another, of the three great secular chapters of York, Lincoln and Salisbury; and in course of time it affected, or even revolutionized, all the 
secular Cathedral bodies in England, as well as others in Wales, Scotland and Ireland.

But though the broad fact of the connexion of these new English institutions with Norman prototypes is indisputably clear, the details of such connexion are much more obscure. The publication by $\mathrm{M}$. Chevalier in his Bibliotheque Liturgique ${ }^{1}$ of the two principal documents descriptive of the ways of the Bayeux Chapter, both constitutional and liturgical, raises a strong hope of light and information upon this topic. Unfortunately, however, the similarities cannot be traced right back to the point of their divergence. These Bayeux documents are of the thirteenth century, a little later in date than the corresponding documents of Salisbury, whereas the creation of the new form of the secular system belongs to the last decade of the eleventh century. Two documents of that date exist for Salisbury and give in outline the plan as S. Osmund introduced it: probably they were the only documents that were then considered necessary, and the rest of the method was brought as oral tradition from Normandy: and if that is so, then all the things that S. Osmund concerned himself to set down in black and white were the legal and constitutional' points on which his scheme for Dean and Secular Canons was to rest, and the whole of the liturgical provision was the importation of the oral tradition. But whether this is so or not, there are at any rate no documents available at present from any Norman cathedral for purposes of comparison with the Carta and the Institutio of S. Osmund: and the comparison, whether on the liturgical or the constitutional side, must be made in the thirteenth century and not in the eleventh.

The two documents from Bayeux now published are an Ordinal dating from the second quarter of the thirteenth century, and a Consuetudinary drawn up by Raoul Langevin in 1270 . The former is an impersonal service-book, such as any methodically minded Chanter might draw up for the Church for whose services he was responsible; and it received additions as time went on, some of them in the form of marginal notes. In this respect it is like the Sarum Ordinal; but in another important respect it differs ; for while the Sarum Ordinal was from the first apparently a twin volume with the Sarum Consuetudinary, and was therefore

1 Ordinasre et Coutumier de lEglise Cathédrale de Bayeux. 8vo. Paris, 1902. 
able to confine itself to its strict sphere of directing the form which the services were to take on any given occasion, leaving to the Consuetudinary the description of liturgical customs in general and the duties of individual persons in regard to those services, the Bayeux Ordinarius evidently stood alone at first, and had to combine both functions : hence here, as in the Ordinals of many churches other than Salisbury, liturgical consuetudines are intermingled with the detailed description of the service. This combination represents no doubt the earlier state of things, as the most ancient Roman Ordines show: and the separation of the two provinces of the Consuetudinary and the Ordinal was a later improvement, which was not always followed even by Churches such as Exeter, which followed the Sarum model : for the Exeter Ordinal combines consuetudines with Ordinal much as does the Bayeux Ordinarius. The convenience, however, of this separation of provinces found recognition at Bayeux; and Langevin in drawing up a separate Consuetudinary extracted the consuetudines from the existing Ordinal, combined them with other documents of a less permanent character, utilized particularly the labours of Subdean W. de Tanquarville, who had made tentative efforts in the same direction before his death in 1240 , and so produced his orderly code of Customs.

It has been thought for some considerable time now that Bayeux and Salisbury would prove to be the pair of foundations between which a comparison could best be made. The reason for this lay in the recognition of the fact that these two Chapters were alike in their constitution, and that especially the order of precedence within the Chapter of the chief dignities of the body was identical. Agreeably with this we find at Bayeux Dean, Chanter, Chancellor, Treasurer as the four principal persons; then follow the four Archdeacons, and then the Subdean, Subchanter, Scholasticus and Custos or Warden, who are the deputies of the four principal persons: and it appears that the Warden's office is a later addition. The same four principal persons appear in like order at Salisbury, York and Lincoln, and after the Archdeacons come the Subdean and the Subchanter: but here divergence begins: at York there figures a Penitentiary, while there is no mention of such a function at Salisbury, and at 
Lincoln it is exercised by the Subdean. In England the Chancellor and the Treasurer had no such deputies, but each was bound to reside and perform his duties in person: and whereas at York a subchancellor and subtreasurer existed, they had no official status. It is true that the Charter of S. Osmund had made provision for an Archischola corresponding to the Bayeux Scholasticus to be the Chancellor's deputy, but in the later documents all his functions are restored to the Chancellor. Moreover, at Bayeux the Chancellor was the Bishop's officer, not bound to residence but to attendance on the Bishop, more analogous therefore to the Bishop's Chancellor or Vicar-General than to the Cathedral Chancellor of the English system. Thus the analogy between the English and the Norman plan is less or became less, in fact, than it seems to be upon the surface.

The chief duties of the Scholasticus abroad, as of the Chancellor in England, are two-to be responsible for the correct reading of the lessons in choir and to take charge of the School: at York as at Bayeux a distinction is drawn between the Grammar-school, over which he presides, and the Song-school which is under the Chanter; but this is not so at Salisbury or at Lincoln. Again, in other respects the duties of these principal officers are differently apportioned in England from the method of Bayeux. There the Dean is responsible for a large part of the ceremonial of the services, in fact for everything but the chant, which belonged to the Chanter, and the reading, which belonged to the Scholasticus: in England he was more exclusively the executive officer of the Chapter in business and disciplinary affairs, and the regulation of the services was more entirely in the hands of the Chanter. Again, sermons form a considerable part of the Chancellor's burden at York and at Lincoln, but it is not so stated at Salisbury, and at Bayeux this function seems to belong to the Dean.

The sum of all this seems to be, that while there is a real connexion between the constitution of Baycux and the constitution of the Norman secular Cathedrals in England, as evidenced by the similarity of the principal dignities of the Chapter, the likeness does not extend far; and there is such variety in detail as to make the differences between the two systems quite as noteworthy as the connexion.

VOL. IV. 
Turning now to the liturgical side of the matter, it soon becomes clear that the divergences far exceed the similarities. There is naturally a strong family likeness between, let us say, the Bayeux Ordinarius and the Sarum Ordinal: a large part of the terminology is identical, and indeed the general impression which results from a perusal of the former is that its terminology is nearer akin to that of Salisbury than to that of York; and again, is nearer akin than is the terminology of the Rheims Ordinal or even of John of Avranches as representing the Use of Rouen. The general outline of the apportionment of the parts of the services to the various singers and readers is the same; and the same method exists of recording this allotment of duties on the tabula. The arrangement of the choir is much the same, the use of the pulpitum or stone screen and of a smaller pulpitum or lectern for lessons and responds is the same, though here there is a difference of phraseology ; for the position which is described at Salisbury as ad gradum chori is here described as ante genas; and these doors of the sanctuary in choro are contrasted with the genae in introitu chori mentioned elsewhere (p. $3^{1}$ ).

But the differences of terminology are more remarkable; the Lent veil is cortina not velum, the chalice veil is syndon not offertorium, the humeral veil is pallium not mantellum; while the following terms are strangers to English rubrics, archichorus (as the equivalent and alternative of rector chori), incensifer, missalifer, urcifer, \&c. More remarkable still is the classification of days : the term feria is not used at all to express a day which is not a festival, but this is expressed either by the phrase fit de dieta or by the phrase fit sine festo. The last expression is also adapted to describe what was described at Salisbury by memoria tantum, namely a saint's day without a festival service : this here takes the somewhat paradoxical description festum sine festo.

Passing from mere terminology to the system of services itself, conspicuous differences appear : the whole method of classification of festivals is simpler than at Salisbury. Simple feasts are of two classes, divided according as the number of lessons was three or nine. Double feasts are divided into three classes; the lowest is cum duabus cappis, i. e. with two Rulers, the highest is with four Rulers of the upper stalls, while the intermediate has four Rulers, two of whom are of the upper row and two of the 
second row of clergy. Bayeux thus agrees with Salisbury in dividing festivals into two classes-duplex and simplex-and they differ from other churches such as Lincoln or Exeter, where there was an intermediate class called semi-duplex, probably a later refinement, and probably, so far as England is concerned, a method borrowed from Roman Use.

The further that inquiry is made into detail, the greater are the differences that emerge : the allotment of duties at services, though it agrees in main principles at Sarum and Bayeux, differs endlessly in detail. Again, the customs as to dress differ; the Chanter at Bayeux has a magnificent dress of his own, including not only a staff but gloves and a mitre: the alb and amice are constantly ordered where at Salisbury a surplice was customary ; and on occasion taperers and thurifers come out in the glory of tunicles. But while some of these rules seem contrary to the similar rules of Sarum Use, it is evident that others are not incompatible, and indeed may actually fill up gaps in the knowledge of English ceremonial. It is worth while from this point of view to make a brief comparison of the ordinary ceremonial of the Mass as laid down for the two churches.

Bayeux is more explicit than Sarum as to the actions of Deacon and Subdeacon, but far less explicit as to the other ministers-acolyte, thurifer, \&c. At the approach to the altar there is no censing at Bayeux, but the incense is first blessed before the reading of the Gospel: on the other hand, directions are given for the celebrant (or Bishop) to turn to the people to say the Absolution, and for the Bishop, if he is not the celebrant, to return to his seat after he has said the Confession and Absolution before the altar and kissed the Sacred Ministers : also when they go up to the altar the Deacon and Subdeacon adornent altare debitis ornamentis, sacerdote interim officium quod sibi incumbit prosequente. These are directions additional to those of the Sarum rite, and may very possibly represent what was customarily done though not laid down in the books.

The directions given in the books of Bayeux concerning the reading of the Gospel are clearer: for there were innovations in the ceremonial introduced at Salisbury which have somewhat confused the existing directions. On the way to the Screen at Bayeux the Deacon carried the Gospel-book closed 
and the Subdeacon carried the cushion : at Salisbury apparently two books were carried, one, the liber euangelice leccionis, by the Subdeacon, and the other, or 'text,' by the Deacon. At their return the Bayeux Use agrees with the older Sarum custom which kept the kissing of the text with its accompanying censing in its proper place immediately following the Gospel; and does not agree with the later Sarum custom, which deferred these ceremonies (probably out of respect for the Creed) till after the offertory was done, and thus appended them not to the ceremony of the Gospel, to which they properly belong, but to the ceremony of the oblation, from which historically they are quite distinct.

The oblation is more fully described for Bayeux than for Sarum. The Subdeacon on returning from reading the Epistle receives a blessing from the celebrant, places his book on the north side of the altar, and sets there also the Altar desk-called paroum pulpitum-and the Missal: he then brings up the superaltar and the corporals non nuda sed panno ad hoc dedito involuta: he leaves them on the altar, setting the rudimentary corporas case on the north side of the altar: he then prepares paten and chalice. which have not hitherto been mentioned, folding up separately the cloths in which they had been wrapped, places paten on chalice, covers both with the chalice veil (syndon), and so holds them out for the blessing of bishop or celebrant, and sets them down again as before. This again agrees with the older more than with the later custom at Salisbury.

After the offertory has been finished-

'Acolitus transverso pallio preindutus afferat ibidem subdiacono calicem sollempniter, sicut ipse subdiaconus illum dimiserat sindone supertectum : quem subdiaconus discooperiens, reuerenter accipiat in manibus cum sui brachiis manipuli patenam cum oblata; quam diaconus accipiat de manu eius cum suo similiter manipulo et tradat eam sacerdoti : tandem subdiaconus sumens de manu acoliti calicem cum sindone, ipso acolito deosculante manum eius, tradat eum dyacono, dicens Totum; et osculetur ipse subdiaconus manum diaconi. Tunc procedens acolitus stet ante maius candelabrum. Recipiens igitur diaconus calicem similiter cum sindone, tradat illum sacerdoti, dicens Totum, et osculetur manum eius. Tunc sacerdos signans calicem accipiat sine sindone, et ponat 
illum loco debito; deinde diaconus accipiens patenam cum sindone tradat eam subdiacono, qui deosculans manum eius cum sindone recipiat eam et tradat eam acolito ubi ipse stat, parte syndonis supposita ipsi patene et parte alia eandem protegente ; et osculetur acolitus manus eius in recipiendo.'

There is, except for the final handing of the paten to the acolyte, nothing in this contrary to the Sarum rules; but there is very much that is explanatory and valuable. The additional censing which now follows corresponds to the later Sarum Use, and comprises, besides the censing of the oblations, a triple censing of the priest, a censing of altar and relics (the priest meanwhile receiving oblations from any who may be there to offer), and then a fresh censing of the ministers and of the quire.

The central part of the service is very barely described; and it is not till after the priest's communion that the regulations again become full. Several differences from the Sarum rite are indicated, the acolyte with humeral veil ministers the ablutions, not the Subdeacon, who is busy moving the desk to the south end of the altar, while the Deacon moves the book. A description is given of the renewal of the Reserved Sacrament; and then the restoration of paten and chalice to the place where they were before being in use is very fully described, on the same lines as the description of their presentation at the altar: it is noticeable that in this, as in the handling of the pyx containing the Reserved Sacrament, the Subdeacon uses the sindon or chalice veil just as the acolyte uses the pallium or humeral veil. These instances will serve to show in what way the Bayeux and the Sarum rites diverge, and in what way they may perhaps explain one another's silences : and this is perhaps as fair an idea as can be briefly given of the relation of the one to the other.

Lastly, one or two instances may be given of ritual divergence as distinct from ceremonial differences: the most interesting are those that exist in the central framework of the hours: thus at Prime it has come to pass that the Bayeux Use groups the Quicunque with the rest of the psalms of Prime, omitting the first part of Psalm cxviii (cxix), and uses the antiphon of Quicunque for the group and not a psalm-antiphon or the first of the antiphons of Lauds. This latter consequently is used at Terce, the second antiphon of Lauds at Sext, and the third at None, 
where Sarum normally uses the second, third, and fifth. The suffrages also present interesting points of difference: those of Prime are rather fuller at Bayeux than at Sarum, while on ferial days the set for Terce, Sext, and None differ there from the set used at Lauds and Evensong. The latter set retain a good many, and the former a few, of the triple suffrages, consisting originally of a bidding followed by versicle and response; only one such has survived at Salisbury, and there as here in a mutilated form. The biddings are-'Oremus pro omni gradu . . . Pro pastore nostro ... Pro rege nostro ... etc. ...; ; but the prayer has been reduced to a single response. The penitential psalms form part of the suffrages at Bayeux in Advent as well as in Lent. In other respects, too, the rite is more elaborate: the antiphons of the Gospel canticles are sometimes repeated before the Gloria patri as well as after it, like an Introit Antiphon, tropes are more often used and the processions are elaborated: but in other respects Bayeux is the simpler of the two; its system of Memorials is far less complicated, and the recitation of the secondary service of the B. V. M. is restricted to a smaller number of days.

Here then again in the liturgical sphere, as before in the constitutional sphere, the same general impression is reached, that the two rites, though similar, are also very different; and some of the differences are of a somewhat fundamental sort. The similarity would probably have been found greater, if it had been possible to make the comparison in the eleventh century instead of in the thirteenth: much development took place in the interval, and it is not surprising that even if they had started identical at the earlier date they should find themselves at considerable variance at the later epoch.

W. H. FRERE. 